\title{
DAYA TETAS TELUR CUMI-CUMI (Uroteuthis chinensis) PADA SALINITAS YANG BERBEDA
}

\section{HATCHING RATE OF MITRE SQUID EGGS (Uroteuthis chinensis) ON DIFFERENT SALINITY}

\section{Jaya Samputra Pirmansa ${ }^{1}$, Eva Prasetiyono ${ }^{1} *$, Suci Puspita Sari ${ }^{2}$, Dwi Febrianti $^{3}$, Ahmad Fahrul Syarif ${ }^{1}$}

\author{
${ }^{1}$ Program Studi Akuakultur, Fakultas Pertanian Perikanan dan Biologi, \\ ${ }^{2}$ Program Studi IImu Kelautan, Fakultas Pertanian Perikanan dan Biologi, \\ Universitas Bangka Belitung \\ Kampus Terpadu UBB, Gedung Teladan, Bangka, Kepulauan Bangka Belitung, 33172 Indonesia \\ ${ }^{3}$ Pusat Penelitian Limnologi, Lembaga IImu Pengetahuan Indonesia \\ Jl. Raya Bogor Km 46, Cibinong, Bogor, Jawa Barat 16911 Indonesia \\ Email: evaintegral@gmail.com
}

\begin{abstract}
ABSTRAK
Salinitas mempengaruhi keberhasilan penetasan telur cumi-cumi. Tujuan dari penetasan telur pada dasarnya untuk menjaga ketersediaan stok cumi-cumi. Penelitian dilaksanakan pada bulan Maret - April 2017. Tujuan mengkaji pengaruh salinitas terhadap daya tetas telur cumi-cumi dan mengkaji salinitas optimal untuk penetasan telur cumi-cumi. Metode yang digunakan pada penelitian ini adalah ekperimen. Penelitian dilakukan di Hatchery Budidaya Perairan Fakultas pertanian, perikanan dan biologi Universitas Bangka Belitung. Bahan penelitian berasal dari perairan Dusun Tuing Kecamatan Riau Silip. Data bentuk kapsul telur dan waktu penetasan dianalisis secara deskriptif, sedangkan Hatching Rate, kematian telur, pertambahan bobot kapsul telur dan kualitas air dilakukan sidik ragam. Telur menetas paling cepat pada perlakuan salinitas $32 \mathrm{~g} / \mathrm{l}$ yaitu 12 hari dan terendah pada salinitas $24 \mathrm{~g} / \mathrm{l}$ yaitu 19 hari. Hasil Hatching rate terbaik pada salinitas $28 \mathrm{~g} / \mathrm{l}$ dengan rerata $96 \% \pm 6,10$ dan $32 \mathrm{~g} / \mathrm{l}$ dengan rerata $92,67 \% \pm 6,89$. Kematian larva cumi-cumi tertinggi pada salinitas $24 \mathrm{~g} / \mathrm{l}$ dengan rerata 77,1 \% $\pm 16,26$ dan terendah pada salinitas $28 \mathrm{~g} / \mathrm{l}$ dengan rerata $4,1 \% \pm 2,88$.
\end{abstract}

Kata kunci : Salinitas, telur cumi-cumi, penetasan, Uroteuthis chinensis

\begin{abstract}
Salinity influences squid hatching rates. Hatching eggs is purpose to keep the availability stock squid. The research has been done in March - April 2017. This research aims to evaluate the effect of salinity for squid eggs hatching rate. The method used in this research was experiment. The research was in Aquaculture Hatchery, Faculty of Agriculture, Fishery and Biology of TheUniversity of Bangka Belitung. The squid eggs was from the the Sea of Riau Silip (Tuing village). The squid eggs data and hatching time were analyzed descriptively. Hatching Rate, mortality, increase of squid eggs and water quality were analyzed with ANOVA. The result showed that the fastest hatching time on the salinity was $32 \mathrm{~g} / \mathrm{l}$ and the lowest salinity was $24 \mathrm{~g} / \mathrm{l}$. The Results of best hatching rate on the salinity was $28 \mathrm{~g} / \mathrm{l}$ and $32 \mathrm{~g} / \mathrm{lwith}$ the value of each salinity were $96 \% \pm 6,10$ and $92,67 \% \pm 6,89$. The squid larva mortality was highest at salinity $24 \mathrm{~g} / \mathrm{l}$ with the value was $77,1 \% \pm 16,26$ and The lowest on the salinity was $28 \mathrm{~g} / \mathrm{l}$ with the value was $4,1 \% \pm 2,88$.
\end{abstract}

Keywords : Salinity, mitre squid eggs, hatching, Uroteuthis chinensis

\section{PENDAHULUAN}

Cumi-cumi merupakan salah satu komoditas perikanan laut yang memiliki kadar protein yang cukup tinggi yaitu 15,6\% (Wini et al., 2004). Namun untuk mendapatkan cumi-cumi, nelayan masih mengandalkan hasil dari alam. Padahal alam mempunyai keterbatasan daya dukung. Hal ini membuat kegiatan penangkapan tidak bisa dilakukan setiap saat. Menurut Collins et al. (1997) pada perairan tropis pemijahan cumi-cumi dalam satu tahun hanya terjadi satu kali pemijahan yang berlangsung pada 
bulan Oktober hingga Januari. Kondisi ini membuat komoditas cumi-cumi ini menjadi terbatas. Oleh sebab itu perlu dilakukan tindakan untuk menjaga ketersediaan stok cumi-cumi di alam. Menurut Baskoro (2007) untuk mengatasi ketersediaan stok cumicumi di alam dapat dilakukan dengan cara membudidayakan komoditas cumi-cumi walaupun masih mengandalkan pemijahan di habitatnya. Kegiatan yang dapat dilakukan untuk mengatasi ketersediaan stok cumicumi ialah pengambilan kapsul telur cumicumi di perairan laut dengan menggunakan alat yaitu jaring insang dan atraktor untuk ditetaskan diwadah yang terkontrol. Atraktor merupakan wadah yang digunakan sebagai tempat cumi-cumi menempelkan telurnya sedangkan jaring insang ialah jaring yang digunakan nelayan. Menurut Baskoro et al. (2011) atraktor cumi-cumi dengan substrat pelekatan telur dari bahan tali rami dapat digunakan sebagai tempat menempelnya telur cumi-cumi.

Cumi-cumi pada lingkungan habitatnya akan menempelkan telurnya pada substrat yang memiliki daya lekat, sampai waktu penetasannya. Tulak (1999), mengemukakan bahwa substrat yang disukai cumi-cumi adalah sponge, bubu bambu, tali jangkar kapal, keramba jaring apung, kerangka besi, jaring nelayan. Namun substrat yang paling disukainya adalah yang menyerupai pita dan barang/ranting. Bahan substrat tidak menjadi objek perhatian cumi-cumi, melainkan bentuk dan letak substrat. Berdasarkan penelitian Aras (2013) keberhasilan penetasan di alam bergantung dari kondisi lingkungan alamnya dikarenakan telur yang telah melekat pada substrat akan diganggu oleh ikan-ikan karang disekitarnya. Ikan tersebut mengigit pakal telur pada substrat sampai telur terlepas. Oleh karena itu, perlu dilakukan kegiatan penetasan telur cumi-cumi di wadah terkontrol agar daya penetasan telur cumicumi tinggi.

Kegiatan penetasan kapsul telur cumicumi harus memperhatikan parameter kualitas air. Hal ini dikarenakan faktor faktor kualitas air merupakan faktor utama penyebab kegagalan dalam kegiatan penetasan. Pada prinsipnya semua lingkungan perairan yang di dalamnya terdapat kehidupan biota air dapat digunakan untuk budidaya biota air tertentu. Menurut Nybakken (1988) parameter kualitas air merupakan faktor pembatas terhadap jenis biota air yang dibudidaya di suatu perairan. Beberapa aspek oseanografi kimia yang dapat mempengaruhi kualitas air dan kehidupan biota laut yang akan dibudidaya seperti suhu, salinitas, $\mathrm{pH}$ dan mineral anorganik. Aspek-aspek tersebut secara langsung maupun tidak langsung mempunyai pengaruh yang sangat besar terhadap pertumbuhan telur cumi-cumi. Parameter seperti suhu dan salinitas merupakan faktor pembatas di laut. Menurut Hutabarat dan Evans (1986) suhu mempengaruhi aktivitas metabolisme maupun perkembangan dari organisme-organisme dan salinitas akan mempengaruhi jasad-jasad biota air melalui pengendalian berat jenis dan keragaman tekanan osmotik.

Salinitas merupakan parameter lingkungan yang mempengaruhi proses biologi dan secara langsung akan mempengaruhi kehidupan organisme antara lain mempengaruhi laju pertumbuhan, jumlah makanan yang dikonsumsi, nilai konversi makanan, dan kelangsungan hidup (Aliyas et al., 2015). Menurut Aras (2013) salinitas dan suhu air selama penetasan akan berpengaruh terhadap perkembangan embrio di dalam telur sehingga akan mempengaruhi keberhasilan penetasan. Berdasarkan penelitian Takdir (2004) rendahnya daya tetas telur cumi-cumi dikarenakan tidak memperhatikan perlakukan salinitas dan suhu.

Berdasarkan hal tersebut diatas, maka perlu dilakukan penelitian untuk mengetahui sejauh mana pengaruh salinitas terhadap daya tetas telur cumi-cumi (Uroteuthis chinensis) serta berapa salinitas yang optimal untuk penetasan telur cumi-cumi. Oleh karena itu penulis melakukan penelitian Daya tetas telur cumi-cumi (Uroteuthis chinensis) pada salinitas media yang berbeda.

\section{METODE PENELITIAN}

Penelitian ini dilakukan di Hatchery jurusan Budidaya Perairan Fakultas Pertanian, Perikanan dan Biologi Universitas Bangka Belitung pada Bulan Maret - April 2017. Alat-alat yang digunakan dalam penelitian ini yaitu wadah pemeliharaan dengan volume $5 \mathrm{~L}$, blower, heater, $\mathrm{pH}$ meter, DO meter, termometer, salinometer. Bahan-bahan yang digunakan yaitu kapsul telur cumu-cumi, air laut, air tawar, garam kasar.

Penelitian ini menggunakan metode eksperimen. Rancangan perlakuan yang digunakan adalah Rancangan Acak Lengkap (RAL) dengan 4 perlakuan masing-masing 3 ulangan. Perlakuan pada penelitian ini menggunakan media pemeliharaan kapsul telur cumi-cumi dengan salinitas tertentu. 
Rincian perlakuan yaitu, Perlakuan $A=$ Kapsul telur cumi-cumi yang dipelihara pada salinitas $24 \mathrm{~g} / \mathrm{l}$; Perlakuan $\mathrm{B}=$ Kapsul telur cumi-cumi yang dipelihara pada salinitas 28 $\mathrm{g} / \mathrm{l}$; Perlakuan $\mathrm{C}=$ Kapsul telur cumi-cumi yang dipelihara pada salinitas $32 \mathrm{~g} / \mathrm{l}$; Perlakuan $D=$ Kapsul telur cumi-cumi yang dipelihara pada salinitas $36 \mathrm{~g} / \mathrm{l}$.

Penentuan salinitas ini mengacu pada Nabhitabhata et al. (2001) yang menyatakan bahwa telur cumi-cumi dapat hidup pada salinitas 21,8-36 $\mathrm{g} / \mathrm{l}$. Pemeliharaan telur pada masing-masing perlakuan selama 21 hari. Berdasarkan Tallo (2006) telur cumicumi menetas di hari ke-30 tanpa perlakuan salinitas. Kapsul telur yang digunakan yaitu kapsul yang berumur muda dengan ciri-ciri kapsul berbentuk oval memanjang dan berwarna putih. Jumlah kapsul untuk setiap toples plastik yaitu sebanyak 7 butir kapsul telur. Air laut yang dibutuhkan untuk setiap toples sebanyak 2,5 Liter. Sehingga jumlah kapsul telur yang dibutuhkan untuk semua perlakuan dan ulangan sebanyak 84 butir kapsul telur.

\section{Persiapan wadah penetasan}

Wadah yang digunakan dalam penelitian adalah toples plastik berkapasitas $5000 \mathrm{ml}$ sebanyak 12 buah. Kemudian, setiap wadah diisi air sebanyak $2.500 \mathrm{ml}$ dengan perlakuan salinitas yang berbeda dan diberi aerasi serta pemanas (heater) dengan suhu $30{ }^{\circ} \mathrm{C}$. Berdasarkan penelitian Omar (2002) suhu $30{ }^{\circ} \mathrm{C}$ merupakan suhu terbaik untuk penetasan telur cumi-cumi. Air laut yang diisi sebelumnya telah disaring sehingga bebas kotoran dan mikroorganisme.

\section{Pembuatan media air dengan salinitas berbeda}

Air yang digunakan dalam penelitian ini menggunakan air laut. Akan tetapi untuk mendapatkan salinitas yang lebih rendah maka dilakukan pengeceran dengan air tawar. Pengenceran dilakukan menggunakan rumus : (Arrokhman et al., 2012)

$$
M_{1} \times V_{1}=M_{2} \times V_{2}
$$

Keterangan: $M_{1}=$ Salinitas air laut yang diencerkan $(\mathrm{g} / \mathrm{l}) ; \mathrm{V}_{1}=$ Volume air laut yang diencerkan (L); $M_{2}=$ Salinitas yang diinginkan $(\mathrm{g} / \mathrm{l}) ; \mathrm{V}_{2}=$ Volume air dengan salinitas yang diinginkan ( $L$ )

Setiap wadah perlakuan diisi air laut perairan Dusun Tuing dengan volume 2.500 $\mathrm{ml}$ dan diisi kapsul telur cumi-cumi sebanyak 7 butir kapsul telur pada masing-masing perlakuan. Perlakuan pada wadah yang memiliki perbedaan salinitas dengan salinitas kontrol dilakukan pengenceran secara gradual yaitu menaikkan dan menurunkan 2 $\mathrm{g} / \mathrm{l} /$ hari. Pada perlakuan $32 \mathrm{~g} / \mathrm{l}$ dan $36 \mathrm{~g} / \mathrm{l}$ dilakukan penambahan garam kasar sebanyak 6,8 gram garam kasar untuk $2 \mathrm{~g} / \mathrm{l}$ dalam $500 \mathrm{ml}$ air, sedangkan untuk perlakuan $24 \mathrm{~g} / \mathrm{l}$ dilakukan pengenceran pertama dengan menambahkan air tawar sebanyak $2.150 \mathrm{ml}$ untuk $2 \mathrm{~g} / \mathrm{l}$ dengan volume awal air laut $2.000 \mathrm{ml}$, setelah itu dilakukan pengurangan volume air dalam wadah sebanyak $2.150 \mathrm{ml}$ sebelum melakukan pengenceran yang kedua.

\section{Pengambilan kapsul telur}

Kapsul telur cumi-cumi untuk penelitian berasal dari alam di perairan laut Desa Mapur Dusun Tuing Kecamatan Riau Silip. kapsul telur diperoleh dengan cara mengunakan jaring insang, yaitu pada saat nelayan menebar jaring insang kapsul telur cumi-cumi akan melekat pada jaring tersebut.

\section{Seleksi kapsul telur}

Kapsul yang digunakan dalam penelitian ini yaitu Kapsul telur yang masih berumur muda dengan ciri-ciri berbentuk kapsul yang sudah mempunyai bentuk oval memanjang dan berwarna putih.

\section{Penebaran kapsul telur}

Kapsul telur yang akan digunakan dalam penelitian ini sebanyak 7 butir kapsul telur setiap wadah. Penebaran kapsul telur dilakukan setelah air dalam wadah di aerasi selama 24 jam. Pemeliharan kapsul telur dilakukan maksimal 21 hari.

\section{Pengamatan jumlah telur menetas}

Dalam proses penelitian, setiap hari diamati jumlah telur yang menetas pada setiap Toples plastik. Pengamatan telur menetas dilakukan sampai waktu maksimal 21 hari untuk melihat tinggi rendahnya waktu penetasan.

\section{Pengamatan kualitas air}

Pada proses penelitian setiap hari dilakukan pengamatan terhadap Salinitas, Suhu, pH dan DO dilakukan pengecekan 1 kali sehari yaitu sore hari. Kemudian, apabila pada wadah $B, C$, dan $D$ terjadi kenaikan salinitas, maka dilakukan penambahan air 
tawar, sebaliknya jika terjadi penurunan maka dilakukan penambahan larutan garam. Untuk menaikkan dan menurunkan salinitas setiap perlakuan dari salinitas asal dilakukan aklimatisasi secara bertingkat (Omar 2002).

\section{Parameter Penelitian}

Mengamati secara langsung bentuk kapsul telur dengan cara melihat kesempurnaan bentuk telur dan diameter telur. Hal ini bertujuan untuk melihat hubungan antara bentuk telur dengan waktu penetasan.

Menurut Effendie (1997) untuk mengetahui tingkat penetasan telur atau sering disebut Hatching Rate (HR) dapat dihitung dengan rumus sebagai berikut:

$$
\mathrm{HR}=\frac{\text { Jumlah telur yang menetas }}{\text { Jumlah telur yang dibuahi }} \times 100 \%
$$

Parameter kualitas air yang akan diamati dalam penelitian ini adalah Suhu, Salinitas, $\mathrm{PH}$ dan DO. Semua parameter kualitas air diukur setiap hari dengan jumlah 1 kali sehari. Suhu diukur menggunakan thermometer, $\mathrm{pH}$ dengan $\mathrm{pH}-$ meter, salinitas diukur dengan Salinometer dan DO menggunakan DO-meter.

\section{Analisis Data}

Untuk menganalisis data Rancangan Acak Lengkap dilakukan analisis sidik ragam (ANOVA) pada taraf nyata 0.05. Jika perlakuan menunjukkan perbedaan nyata maka diuji lanjut menggunakan uji Tukey's Studentized Range (HSD).

\section{HASIL DAN PEMBAHASAN}

Kapsul telur cumi-cumi dan air laut dalam penelitian ini diperoleh dari perairan Dusun Tuing Kecamatan Riau Silip. Perairan Dusun Tuing memiliki $\mathrm{pH}$ dengan kisaran 7 9, suhu $27-29{ }^{\circ} \mathrm{C}$ dan salinitas yang diperoleh $28 \mathrm{~g} / \mathrm{l}$. Berdasarkan pengamatan selama 21 hari, diperoleh hasil bentuk telur saat memasuki hari pertama penebaran telur sampai memasuki waktu penetasan ditampilkan pada Gambar 1. Kapsul telur muda berumur 1 hari pada saat penebaran di wadah penetasan. Kemudian kapsul telur tua berumur 7-21 hari dari waktu penebaran dan penetasan terjadi pada hari ke 12 - 21 hari.

Kapsul telur cumi-cumi diambil di perairan Dusun Tuing Kecamatan Riau Silip menggunakan jaring insang. Kapsul telur cumi-cumi umumnya melekat pada beberapa substrat seperti akar bahar, jaring tangkap nelayan, tali jangkar kapal dan yang cocok sebagai subtrat penempelan kapsul telur cumi-cumi. Kapsul telur merupakan kumpulan dari telur. Satu kapsul telur umumnya memiliki lebih dari 2 telur. Pada penelitian ini, rerata jumlah telur dalam kaspul yaitu 7 telur per kapsul. Jumlah telur dalam satu kapsul tergantung dari kualitas induk cumi-cumi itu sendiri. Kapsul telur yang digunakan dalam penelitian ini yaitu kapsul telur muda. Berdasarkan pengamatan secara langsung kapsul telur muda memiliki ciri-ciri berbentuk oval memanjang dan berwarna putih. Jumlah telur di dalam kapsul telur belum terlihat pada saat umur telur masih muda dan akan terlihat setelah kapsul telur memasuki umur tua.

Selama penelitian diperoleh perubahan bentuk kapsul telur dari awal penebaran sampai waktu penetasan telur (Gambar 1). Pada hari-1 kapsul telur masih tergolong kapsul telur muda yaitu dengan bentuk oval memanjang dan berwarna putih. Kemudian pada hari ke-7 kapsul telur sudah mengalami perubahan bentuk, yang tergolong kedalam bentuk kapsul telur tua dengan ciri-ciri jumlah telur dalam satu kapsul sudah terlihat dan berwarna putih transparan. Terjadinya perubahan bentuk kapsul telur dikarenakan embrio di dalam kapsul sudah mengalami perkembangan. Kemudian pada saat waktu telur menetas semakin dekat, ukuran telur dalam kapsul semakin besar dan warna kapsul semakin transparan sehingga embrio yang sudah menyerupai morfologi cumi-cumi di dalam telur semakin terlihat jelas.

Data hasil penelitian waktu penetasan telur cumi-cumi ditampilkan pada Gambar 2 waktu penetasan tercepat pada perlakuan salinitas $32 \mathrm{~g} /$ l dengan waktu penetasan 12 hari, sedangkan hasil terendah pada perlakuan salinitas $24 \mathrm{~g} / \mathrm{l}$ dengan waktu penetasan 21 hari. Pada penelitian ini, dilakukan juga pengamatan pertumbuhan bobot kaspul telur cumi-cumi. Bobot merupakan berat total kapsul telur. Pengamatan dilakukan pada saat awal penebaran telur dan saat kapsul telur mau menetas. Adapun hasil pengamatan ditampilkan pada Tabel 1 .

Selama proses penelitian, kapsul telur cumi-cumi ditetaskan selama 21 hari dengan perlakuan salinitas yaitu $24 \mathrm{~g} / \mathrm{l}, 28 \mathrm{~g} / \mathrm{l}, 32 \mathrm{~g} / \mathrm{l}$ dan $36 \mathrm{~g} / \mathrm{l}$. Penentuan batas waktu penetasan telur berdasarkan hasil penelitian Tallo (2006) telur cumi-cumi menetas di hari ke-30 tanpa perlakuan salinitas. 
Berdasarkan data yang diperoleh selama penelitian, waktu penetasan tersingkat dicapai pada perlakuan salinitas $32 \mathrm{~g} / \mathrm{l}$ dan terlama waktu penetasan pada perlakuan salinitas $24 \mathrm{~g} / \mathrm{l}$. Hal ini berarti waktu penetasan dengan perlakuan salinitas $32 \mathrm{~g} / \mathrm{l}$ lebih baik daripada salinitas air yang berasal dari perairan Dusun Tuing.

Perlakuan salinitas $28 \mathrm{~g} / \mathrm{l}$ sampai dengan $32 \mathrm{~g} / \mathrm{l}$ menunjukkan hasil yang baik karena pengaruh dari perubahan salinitas, Danakusumah (2001) menemukan bahwa salinitas mempengaruhi masa penetasan. Semakin tinggi salinitas media yang isoosmotik dengan telur maka waktu penetasan semakin singkat. Menurut Affandi \& Usman (2002) isoosmotik adalah konsentrasi cairan tubuh sama dengan konsentrasi media. Menurut Kinne (1971) Salinitas dapat mempengaruhi fungsional dan struktur dari organisme melalui perubahan : (a) osmokonsentrasi total, (b) proporsi relatif larutan, (c) koefesien absorpsi dan kejenuhan gas-gas terlarut, (d) densitas dan viskositas.

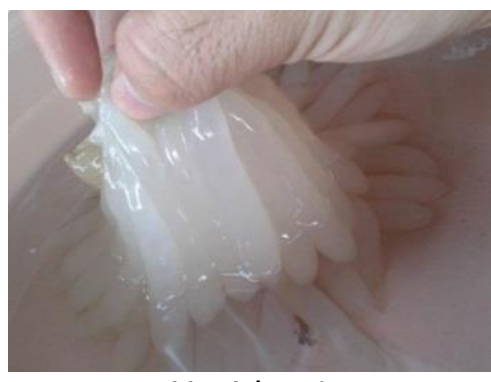

Hari ke-1

(Kapsul telur muda)

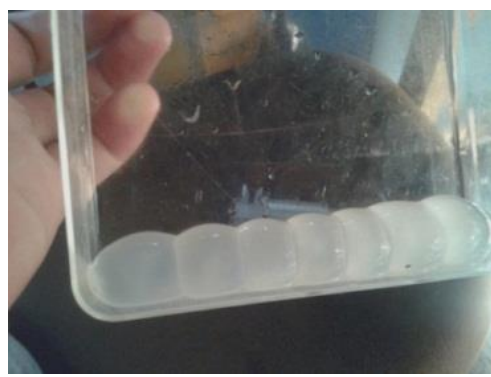

Hari ke- 11

(Hampir menetas)

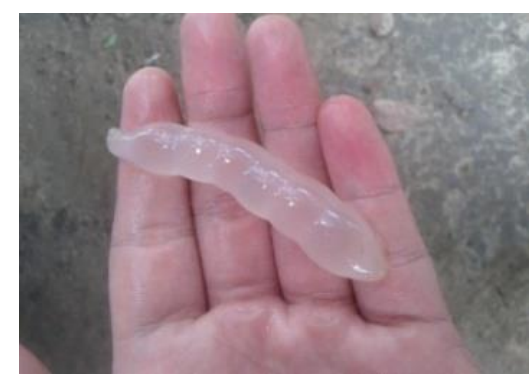

Hari ke-7 (Kapsul telur tua)

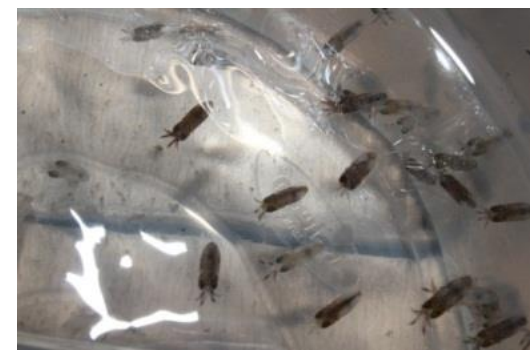

Hari ke- 12

(Larva yang telah menetas)

Gambar 1. Perubahan bentuk kapsul telur cumi-cumi selama penelitian

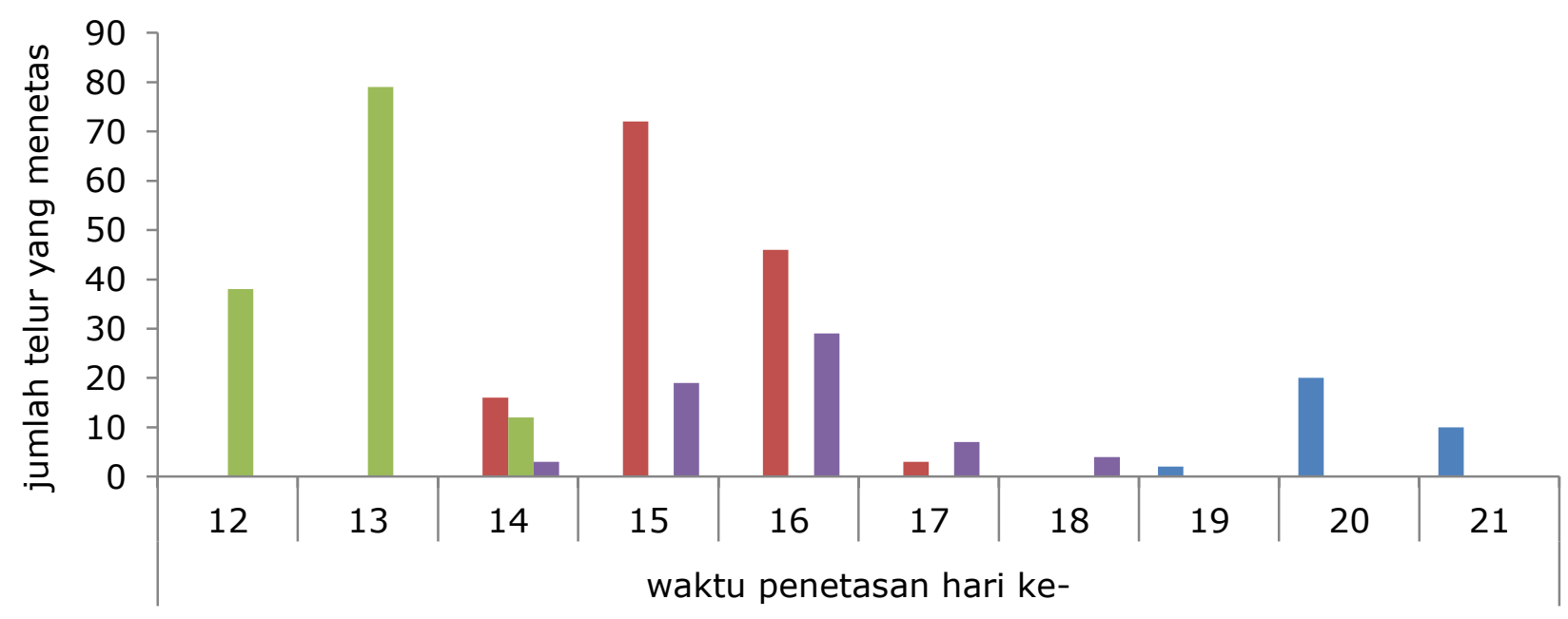

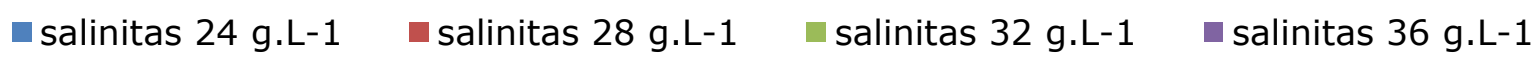

Gambar 1. Waktu penetasan telur cumi-cumi dengan salinitas yang berbeda 
Tabel 1. Rerata pertumbuhan bobot kapsul telur cumi-cumi.

\begin{tabular}{cc}
\hline Perlakuan & $\begin{array}{c}\text { Pertumbuhan bobot kapsul } \\
\text { Telur cumi-cumi (gr) }\end{array}$ \\
\hline Salinitas $24 \mathrm{~g} / \mathrm{l}$ & $61,07 \pm 15,36^{\mathrm{a}}$ \\
Salinitas $28 \mathrm{~g} / \mathrm{l}$ & $88,35 \pm 1,93^{\mathrm{ab}}$ \\
Salinitas $32 \mathrm{~g} / \mathrm{l}$ & $91,73 \pm 1,68^{\mathrm{b}}$ \\
Salinitas $36 \mathrm{~g} / \mathrm{l}$ & $87,3 \pm 1,26^{\mathrm{ab}}$ \\
\hline
\end{tabular}

Keterangan : huruf superscript yang berbeda menunjukkan perbedaan yang nyata $(P<0,05)$

Berdasarkan hasil penelitian didapatkan bahwa penetasan telur cumi-cumi pada salinitas habitatnya (28) $\mathrm{g} / \mathrm{l}$ terjadi pada hari ke-14 setelah penebaran. Tallo (2006) menyatakan bahwa waktu penetasan telur cumi-cumi adalah 30 hari. Berdasarkan kondisi tersebut diduga umur kapsul telur yang diambil dari perairan asalnya yaitu 16 hari, karena pada saat proses penetasan telur cumi-cumi menetas pada hari ke - 14 setelah penebaran. Berdasarkan hal tersebut, kapsul telur cumi-cumi dapat dikategorikan menjadi kapsul telur muda yaitu kapsul telur yang berumur 1-22 hari dan kapsul tua berumur 23-30 hari.

Pada hasil pengamatan pertambahan bobot kapsul telur terlihat jelas bahwa pertambahan bobot kapsul telur terbaik diperoleh pada perlakuan salinitas $32 \mathrm{~g} / \mathrm{l}$, kemudian di ikuti salinitas $28 \mathrm{~g} / \mathrm{l}$. Berdasarkan analisis statistik pada pertambahan bobot telur berpengaruh nyata. Pada pertambahan bobot diperoleh nilai tertinggi pada perlakuan salinitas $32 \mathrm{~g} / \mathrm{l}$ dengan rerata $91,73 \mathrm{~g} \pm 1,68$ dan nilai terendah pada perlakuan salinitas $24 \mathrm{~g} / \mathrm{l}$ dengan rerata $61,07 \mathrm{~g} \pm 15,36$. Terjadinya penambahan bobot kapsul telur cumi-cumi ini diduga karena pengaruh dari salinitas yang berbeda. Menurut Rachmawati et al. (2012), salinitas air merupakan variabel yang berpengaruh langsung terhadap osmolalitas media dan osmoregulasi hewan air.

Kapsul telur cumi-cumi selama masa pemeliharaan mengalami kematian pada setiap perlakuan. Dari hasil pengamatan kematian telur didapatkan rerata kematian telur setiap perlakuan yaitu pada salinitas 24 $\mathrm{g} / \mathrm{l}$ sebanyak $77,1 \% \pm 16.26$, salinitas $28 \mathrm{~g} / \mathrm{l}$ sebanyak $4,1 \% \pm 2,88$, salinitas $32 \mathrm{~g} / \mathrm{l}$ sebanyak 7,1 \% $\pm 2,32$ dan salinitas $36 \mathrm{~g} / \mathrm{l}$ sebanyak $56,1 \% \pm 7,10$. Dari hasil penelitian yang diperoleh terlihat jelas kematian telur tertinggi pada perlakuan salinitas $24 \mathrm{~g} / \mathrm{l}$ dan terendah pada perlakuan salinitas $28 \mathrm{~g} / \mathrm{l}$ (kontrol). Tingginya kematian telur pada perlakuan 24 dan $36 \mathrm{~g} / \mathrm{l}$ diduga oleh perkembangan telur yang abnormal.

Kematian yang terjadi pada perlakuan salinitas $36 \mathrm{~g} / \mathrm{l}$ diduga akibat salinitas media yang tidak isoosmotik dengan telur. Hal ini didukung oleh hasil penelitian Omar (2002) yang dimana pada penelitian tersebut terjadinya kematian massal kapsul telur cumi-cumi pada salinitas yang tinggi yaitu 40 $\mathrm{g} / \mathrm{l}$. Kemudian terjadinya kematian pada salinitas $24 \mathrm{~g} / \mathrm{l}$ diduga karena proses perubahan salinitas dengan menambahkan air tawar. Namun walaupun terjadinya kematian telur pada setiap perlakuan, penetasan telur tetap terjadi pada semua perlakuan. Hal ini karena berdasarkan Nabhitabhata et al. (2001) telur cumi-cumi dapat hidup pada salinitas $21,8-36 \mathrm{~g} / \mathrm{l}$.

Telur yang tidak menetas dikarenakan oleh kematian embrio dalam kapsul telur. Kematian embrio diduga karena pengaruh dari perubahan salinitas yang berkaitan dengan proses osmoregulasi. Menurut Sukendi (2003), pada proses penetasan bersalinitas akan mempengaruhi proses osmoregulasi telur. Hadid et al. (2014) menyatakan kematian embrio akibat dari gejala internal yaitu terganggunya keseimbangan osmolaritas antara media dengan cairan telur (sitoplasma) serta cairan perivitellin, sehingga hanya embrio yang tahan terhadap lingkungan saja yang berhasil menetas.

Selama proses penelitian terjadi kematian telur pada semua perlakuan. Adapun data kematian telur cumi-cumi selama 21 hari pada setiap perlakuan ditampilkan pada Tabel 2. Hasil kematian terbanyak pada perlakuan salinitas $24 \mathrm{~g} / \mathrm{l}$ yaitu sebesar $77,1 \% \pm 16,26$ dan kematian terendah pada salinitas $28 \mathrm{~g} / \mathrm{l}$ yaitu $4,1 \% \pm$ 2,88 .

Data Hatching rate selama 21 hari dengan banyaknya kapsul telur setiap wadahnya 7 butir ditampilan pada Tabel 3 . Hasil hatching rate yang baik terdapat pada perlakuan salinitas $28 \mathrm{~g} / \mathrm{l}$ yaitu $96 \% \pm 6,10$ dan salinitas $32 \mathrm{~g} / \mathrm{l} \quad 92,67 \% \quad \pm \quad 6,89$. Selama proses penelitian selama 21 hari pada perlakuan salinitas 24, 28, 32 dan 36 $\mathrm{g} / \mathrm{l}$ diperoleh daya tetas tertinggi pada salinitas $28 \mathrm{~g} / \mathrm{l}$ dengan rerata $96 \% \pm 6,10$, kemudian diikuti salinitas $32 \mathrm{~g} / \mathrm{l}$ dengan rerata $92,67 \% \pm 6,89$ dan daya tetas terendah diperoleh pada perlakuan salinitas 24 dan $36 \mathrm{~g} / \mathrm{l}$.

Hal ini berarti perlakuan salinitas kontrol yang berasal dari perairan Dusun 
Tuing lebih tinggi dibandingkan perlakuan salinitas lainnya. Terjadinya daya tetas yang rendah pada salinitas 24 dan $36 \mathrm{~g} / \mathrm{l}$ dikarenakan pada saat perkembangan kapsul telur, banyak telur yang mengalami kematian. Walaupun perlakuan kontrol yaitu salinitas $28 \mathrm{~g} / \mathrm{l}$ menunjukkan daya tetas tertinggi dari perlakuan yang lainnya, namun penetasan telur pada salinitas $32 \mathrm{~g} / \mathrm{l}$ merupakan waktu tersingkat daripada perlakuan salinitas $28 \mathrm{~g} / \mathrm{l}$. Pada perlakuan salinitas $32 \mathrm{~g} / \mathrm{I}$ telur mulai menetas pada hari ke-12, sedangkan salinitas $28 \mathrm{~g} / \mathrm{l}$ baru menetas pada hari ke-14 diikuti salinitas 36 $\mathrm{g} / \mathrm{l}$ yang menetas pada hari ke-19. Menurut Kinne (1971) secara umum, salinitas dapat mempengaruhi laju metabolisme, perkembangan, diferensiasi, dan pertumbuhan relating sel-sel dan organorgan. Selain mempengaruhi daya tetas telur Cumi-cumi, salinitas juga mempengaruhi kelangsungan hidup larva cumi-cumi setelah menetas.

Berdasarkan hasil penelitian semua perlakuan mengalami kematian larva setelah menetas, bahkan ada beberapa larva yang mati sebelum menetas. Pada perlakuan salinitas $24 \mathrm{~g} / \mathrm{l}$ mengalami kematian dalam

Tabel 2. Rerata Jumlah kematian telur cumicumi dengan perlakuan salinitas yang berbeda

\begin{tabular}{ll}
\hline Perlakuan & Kematian telur $(\%)$ \\
\hline Salinitas $24 \mathrm{~g} / \mathrm{l}$ & $77.1 \pm 16.26^{\mathrm{b}}$ \\
Salinitas $28 \mathrm{~g} / \mathrm{l}$ & $4.1 \pm 2.88^{\mathrm{a}}$ \\
Salinitas $32 \mathrm{~g} / \mathrm{l}$ & $7.1 \pm 2.32^{\mathrm{a}}$ \\
Salinitas $36 \mathrm{~g} / \mathrm{l}$ & $56.1 \pm 7.10^{\mathrm{b}}$ \\
\hline
\end{tabular}

Keterangan : huruf superscript yang sama menunjukkan tidak berbeda nyata $(P<0,05)$

Tabel 3. Rerata hatching rate telur cumicumi dengan perlakuan salinitas yang berbeda

\begin{tabular}{ll}
\hline Perlakuan & Rerata daya Tetas (\%) \\
\hline Salinitas $24 \mathrm{~g} / \mathrm{l}$ & $23 \pm 1.96^{\mathrm{a}}$ \\
Salinitas $28 \mathrm{~g} / \mathrm{l}$ & $96 \pm 6.10^{\mathrm{c}}$ \\
Salinitas $32 \mathrm{~g} / \mathrm{l}$ & $92,67 \pm 6.89^{\mathrm{c}}$ \\
Salinitas $36 \mathrm{~g} / \mathrm{l}$ & $44 \pm 2.74^{\mathrm{b}}$ \\
\hline
\end{tabular}

Keterangan : huruf superscript yang sama menunjukkan tidak berbeda nyata $(P<0,05)$ waktu 6 jam setelah menetas, hal ini diduga karena larva tidak bisa mentoleransi salinitas $24 \mathrm{~g} / \mathrm{l}$ yang dimana berbeda dengan salinitas habibat cumi-cumi tersebut. Kemudian pada salinitas 28 dan $32 \mathrm{~g} / \mathrm{l}$ larva dapat bertahan hidup selama 2 hari tanpa makanan. Kematian larva setelah menetas diduga karena pergerakan air dalam wadah terlalu besar dan juga karena ada larva yang mati. Kematian larva dalam wadah menyebabkan air bau busuk, sehingga mempengaruhi kehidupan larva lainnya. Sedangkan kematian larva pada perlakuan salinitas 36 $\mathrm{g} / \mathrm{l}$ diduga karena banyak perkembangan embrio yang tidak sempurna, akibatnya larva tidak mampu untuk menembus lapisan kapsul telur. Menurut Boletzky dan Hanlon (1983) cumi-cumi sebagaimana kebanyakan Cephalopoda lainnya, merupakan hewan yang bersifat stenohalin. Stenohalin adalah tingkat adaptasi yang sempit terhadap salinitas yang tinggi.

Menurut Omar (2002), kapsul telur memiliki tiga buah lapisan selubung yaitu : selubung pertama (primary egg envelope) yang disebut dinding/membran telur, berasal dari selaput vitelin (vitelline membrane) atau selaput fetilisasi ; selubung kedua (secondary egg envelope) yang disebut khorion, dibentuk di dalam ovarium oleh sinsitium folikular pada tahap akhir oogenesis/vitellogenesis; dan sebelubung ketiga (tertiary egg envelope) yang disebut jelly (massa gelatin), terbentuk pada saat telur melalui saluran telur atau selama proses deposisi telur.

Kematian larva juga dapat disebabkan proses osmoregulasi, menurut Nabhitabhata et al. (2001) menyatakan bahwa proses osmoregulasi cephalopoda bersifat sangat efektif dan cepat. Selain itu, proses tersebut juga sangat sensitif dan dapat menyebabkan terjadinya mekanisme kematian secara mendadak. Menurut Omar (2002) perubahan salinitas serta rangsangan mekanik juga dapat menyebabkan terjadinya penetasan tidak sempurna sehingga menghasilkan larva yang tidak sehat.

Berdasarkan hasil penelitian yang dilakukan diperoleh hasil pengukuran parameter kualitas air ditampilkan pada Tabel 4. Data kualitas air dianalisis menggunakan ANOVA. Analisis statistik menunjukkan pada parameter $\mathrm{pH}$ tidak berpegaruh nyata, sedangkan DO berpengaruh nyata. Berdasarkan uji lanjut menunjukkan bahwa salinitas $24 \mathrm{~g} / \mathrm{l}$ berbeda nyata dengan salinitas $32 \mathrm{~g} / \mathrm{l}$ dan tidak ada perbedaan yang nyata dengan perlakuan salinitas 28 dan $36 \mathrm{~g} / \mathrm{l}$. 
Tabel 4. Hasil rerata pengukuran kualitas air

\begin{tabular}{lccc}
\hline Perlakuan & Suhu $\left({ }^{\circ} \mathrm{C}\right)$ & $\mathrm{pH}$ & DO $(\mathrm{ppm})$ \\
\hline Salinitas $24 \mathrm{~g} / \mathrm{l}$ & 30 & $8,038 \pm 0,05^{\mathrm{a}}$ & $3,07 \pm 0,06^{\mathrm{a}}$ \\
Salinitas $28 \mathrm{~g} / \mathrm{l}$ & 30 & $8,044 \pm 0,06^{\mathrm{a}}$ & $3,28 \pm 0,06^{\mathrm{ab}}$ \\
Salinitas $32 \mathrm{~g} / \mathrm{l}$ & 30 & $8,022 \pm 0,04^{\mathrm{a}}$ & $3,50 \pm 0,05^{\mathrm{b}}$ \\
Salinitas 36 g/l & 30 & $8,017 \pm 0,06^{\mathrm{a}}$ & $3,33 \pm 0,25^{\mathrm{ab}}$ \\
\hline
\end{tabular}

Keterangan : huruf yang sama menunjukkan tidak berbeda nyata $(p>0,05)$

Hasil pengukuran pada parameter $\mathrm{pH}$ diperoleh rerata $8,030 \pm 0,01$ dan DO dengan rerata 3,29 $\pm 0,15$. Berdasarkan hal ini, diduga kematian larva setelah menetas juga disebabkan oleh kandungan oksigen yang rendah. Menurut Nabhitabhata (2001) menyarankan $\mathrm{pH}$ yang optimal untuk pemeliharaan cumi-cumi berkisar 6,3 - 8,4, serta kandungan oksigen terlarut pemeliharaan cumi-cumi lebih besar dari 5 ppm.

Rukminasari et al. (2014) menyatakan bahwa perubahan nilai $\mathrm{pH}$ suatu perairan tergantung pada suhu air laut, konsentrasi oksigen terlarut dan adanya anion dan kation. Kemudian nilai DO rendah diduga karena pengaruh dari suhu air yang tinggi. Hal ini didukung oleh pernyataan Hutagalung et al. (2017) bahwa semakin tinggi suhu air maka tingkat kelarutan oksigen semakin berkurang. Kurangnya oksigen di perairan dapat menyebabkan perkembangan embrio menjadi lambat dan dapat menyebabkan kematian embrio. Hal ini didukung oleh pendapat Benny (2014) yang menyatakan bahwa penyebab kematian telur selama masa penetasan adalah oksigen terlarut. Terjadinya kandungan oksigen yang rendah juga disebabkan oleh faktor salinitas, sesuai dengan Benny (2014) menyatakan bahwa setiap kenaikan salinitas selalu berkaitan dengan turunnya kandungan oksigen terlarut.

Kualitas dan kuantitas air laut merupakan aspek yang utama dalam pemeliharaan. Secara umum cephalopoda membutuhkan air laut yang bersih dengan jumlah kandungan oksigen yang cukup dan kisaran salinitas yang sempit, tidak seperti hewan moluska lainnya yang hidup menetap. Cephalopoda merupakan hewan yang dapat berpindah tempat untuk menghindari lingkungan yang tidak sesuai. Sehingga di dalam wadah pemeliharaan cephalopoda tidak dapat melakukan hal tersebut, keadaan ini membuat pengawasan kualitas air lebih optimal (Omar, 2002).

\section{KESIMPULAN}

Kesimpulan yang dapat diperoleh dari penelitian ini menunjukkan bahwa salinitas berpengaruh terhadap daya tetas telur cumicumi dengan nilai optimal untuk daya tetas telur cumi-cumi yaitu pada salinitas $28 \mathrm{~g} / \mathrm{l}$ sampai dengan $32 \mathrm{~g} / \mathrm{l}$.

\section{DAFTAR PUSTAKA}

Affandi, R. \& Tang, U.M. 2002. Fisiologi Hewan Air. Pekanbaru : Unri Press

Ali, D., Hartati. R/, Pribadi. R., Sri, R., Astuti, R., \& Septiarani, B. 2016. Pertumbuhan ikan nila larasati (Oreochromis niloticus) di tambak dengan pemberian ransum pakan dan padat penebaran yang berbeda. Jurnal kelautan Tropis, 19(2):131-142. DOI: $10.14710 / j k t . v 19$ i2.840

Aliyas, A., Ndobe, S., \&Raihani. 2015. Pertumbuhan dan kelangsungan hidup ikan nila (Oreochromis sp.) yang dipelihara pada media bersalinitas. Jurnal Sains dan Teknologi, 5(1):20-27.

Aras, M. 2008. Uji Coba Pemasangan Atraktor Cumi-Cumi di Perairan Pulau Pute Anging Kabupaten Barru. Lutjanus : Bulletin Politeknik Pertanian Bidang Perikanan, No 14. Politeknik Negeri Pangkep.

Arikuntoro, S. 2002. Prosedur Penelitian Suatu Pendekatan Praktek. Jakarta : PT. Rineka Cipta

Arrokhman, S., Abdulgari, N. \& Hidayati, D. 2012. Survival rate ikan Bawal Bintang (Trachinotus blochi) dalam media pemelihaan menggunakan rekayasa salinitas. Jurnal Sains dan Seni. 1(1):12.

Baskoro, M,S. 2008. Atraktor Rangsang Cumi-Cumi Bertelur. diakses tanggal 24 Oktober 2019.

Baskoro, M.S. \& Mustaruddin. 2007. Atraktor Cumi-Cumi: Teknologi Potensial dan Tepat Guna untuk Pengembangan 
Kawasan Pantai Terpadu. Prosiding Perikanan Tangkap. 1(1):1-5

Baskoro, M.S., Taurusman, A.A. \& Sudirman. 2011. Tingkah Laku Ikan. Bogor : Lubuk Agung. $257 \mathrm{hlm}$.

Benny, H. 2014. Pengaruh salinitas terhadap penetasan telur ikan sambal siam (Pangasius Hypopthalmus). Jurnal Akuakultur Rawa Indonesia, 2(1):1323.

Collins, M.A., Pierce, G.J. \& Boyle, P.R. 1997. Population Indicates of Reproduction and Recruitmen in Loligo forbesi (Cephalopoda : Loliginidae) in Scotish ang Irish Waters. Journal of Applied Ecology, 34(1):778-786.

Danakusumah, E., 2001. Effects of Salinity on Incubation Time and Hatching of Spineless Cuttlefish Sepiella inermis Linne. Phuket Marine Biological Center Special Publication, 25(1):149-151.

Effendie, M.I. 1997. Biologi perikanan. Yogyakarta : Yayasan Pustaka Nusantara.

Hadid, Y., Syaifudin, M., \& Amin, M. 2014. Pengaruh salinitas terhadap daya tetas telur ikan baung (Hemibagrus nemunes blkr). Palembang. Jurnal Akuakultur Rawa Indonesia, 2(1):78-92

Hanlon, R.T., Hixon, R.F. \& Hulet, W.H., 1983. Survival, growth, and behavior of the Ioliginid squids Loligo plei, Loligo pealei, and Lolliguncula brevis (Mollusca: Cephalopoda) in closed sea water systems. The Biological Bulletin, 165(3):637-685.

Hutabarat, S. \& Evans. 2006. Pengantar Oseanografi. Jakarta : UI Press.

Hutabarat \& Evans. 1986. Kunci Identifikasi Plankton. Jakarta : UI Press.

Jacobson. 2005. Longfin inshore Squid, Loligo pealeii, Life History and Habitat Characteristics. US : Second Edition. U.

S. Department Of Commerce.

Kinne, R., Schmitz, J.E. \& Kinne-Saffran, E., 1971. The localization of the $\mathrm{Na}+-\mathrm{K}+-$ ATPase in the cells of rat kidney cortex. Pflügers Archiv, 329(3):191-206.

Nabhitabhata, J., Asawangkune, P., Amornjaruchit, S. \& Promboon, P., 2001. Tolerance of eggs and hatchlings of neritic cephalopods to salinity changes. Phuket Marine Biological Center Special Publication, 25(1):91-99.

Nontji, A. 1987. Laut Nusantara. Jakarta : Djambatan
Nybakken, J.W. 1988. Biologi Laut. Suatu Pendekatan Ekologi. Alih Bahasa : H.M. Eidman, dkk., Marine Biology An ecological approach. Jakarta : Gramedia.

Omar, A.S.B. 2002. Biologi Reproduksi CumiCumi (Sepioteuthis Lessoniana LESSON, 1830). [Tesis]. Program Pasca Sarjana. Institut Pertanian Bogor.

Rachmawati, D., Hutabarat, J. \& Anggoro, S. 2012. Pengaruh salinitas media berbeda terhadap pertumbuhan keong macan (Babylonia spirata L.) pada proses domestikasi. Jurnal IImu Kelautan, 17 (3) : 141-147

Rukminasari, N., Nadiarti, N. \& Awaluddin, K. 2014. Pengaruh derajat keasaman $(\mathrm{pH})$ air laut terhadap konsentrasi kalsium dan laju pertumbuhan Halimeda sp. Jurnal Ilmu Kelautan dan Perikanan, 24 (1) : 28-34

Sastrosupadi, A. 2000. Rancangan Percobaan Praktis Bidang Pertanian. Yogyakarta : Kanisius. 276 hal

Sukendi. 2003. Vitelogenesis dan manipulasi fertilisasi pada ikan. Universitas Riau. Pekan baru. 110 hal.

Hutagalung, J., Alawi, H. \& Sukendi, S. 2017. Pengaruh suhu dan oksigen terhadap penetasan telur dan kelulushidupan awal larva ikan pawas (Osteochilus hasselti C.V). Jurnal Online Mahasiswa, 4(1) : 1-13.

Suryabrata, S. 1983. Metodologi Penelitian. Jakarta : Rajawali.

Suwignyo, S., 1989. Avertebrata Air. Lembaga Sumberdaya Informasi. Bogor : Fakultas Perikanan. IPB. 123 hal.

Takdir, M. 2004. Penetasan Telur, Pemeliharaan Larva, dan Biologi Reproduksi Cumi-Cumi, Sepioteuthis Lessoniana Lesson. Makalah Falsafah Sains (PPS702) Sekolah Pasca Sarjana / S3. Institut Pertanian Bogor.

Tallo, I. 2006. Perbedaan Jenis dan Kedalaman Pemasangan Atraktor Terhadap Penempelan Telur Cumi-cumi. (Tesis) Sekolah Pasca Sarjana IPB. Bogor dalam 115-255-2.PB

Tulak, D.C. 1999. Pengamatan Substrat Penempelan Telur Cumi-cumi Sirip Besar (Sepioteuthis lessoniana) di Habitat Pemijahan Perairan Teluk Banten [Skripsi]. Fakultas Perikanan, Institut Pertanian Bogor. 
Winni, T., Erungan, S. \& Mardi, S. 2004. Pengaruh suhu dan lama pengovenan terhadap karakteristik cumi-cumi
(Loligo sp.) kertas. Bulletin Teknologi Hasil Perikanan, 8(2):1-8, 